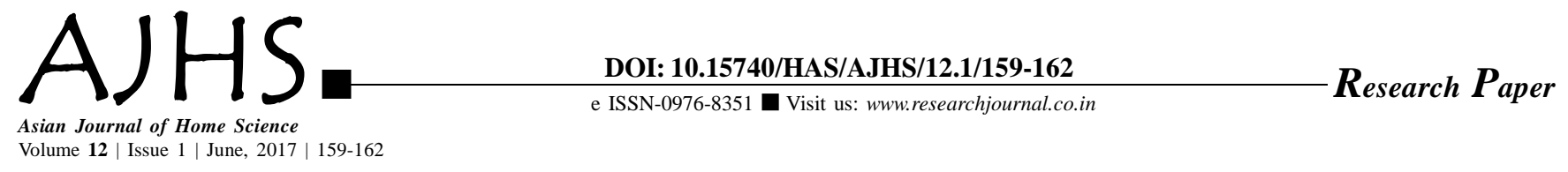

\title{
Analysis of causal factors for academic backwardness of rural school children
}

\author{
SARASWATI HUNSHAL, P.S. HUNDEKAR AND S. PATIL
}

Received: 16.01.2017; Revised: 14.04.2017; Accepted: 01.05.2017

See end of the paper for authors' affiliations SARASWATI HUNSHAL AICRP-RHSc (CD), MARS, UAS, DHARWAD (KARNATAKA) INDIA
ABSTRACT : The study examined the causal factors related to academic backwardness in school going children. The sample comprised of 211 academically backward children studying in $7^{\text {th }}, 8^{\text {th }}$ and $9^{\text {th }}$ standards (13-14 years) from four villages of Dharwad. The identification of academically backward children was made based on two criteria that is academic performance of the children in the previous year (those who secure ' $C$ ' grade and attending remedial classes) and opinion of their respective class teachers. Self structured tool was used to identify the reasons behind academic backwardness of children. The results revealed that the academic backwardness among children were related to academic, familial and health aspects. However 70 per cent of children had problems related to academic aspect that is difficulty in understanding few subjects, problems in writing and answering questions during exam. About 25 per cent had problems related familial aspects such as lack of education of parents, lack of co-operation and involvement in the studies by family members. Further health factors such as feeling tired, often headache, and difficulty in hearing were the major causal factors for academic backwardness in children. Hence, it is concluded that multiple factors were responsible for academic backwardness among rural school children which needs attention by the parents and teachers.

KEY WORDS: Academic backwardness, Causal factors, Grade

- HOW TO CITE THIS PAPER : Hunshal, Saraswati, Hundekar, P.S. and Patil, S. (2017). Analysis of causal factors for academic backwardness of rural school children. Asian J. Home Sci., 12 (1) : 159-162, DOI: 10.15740/HAS/AJHS/12.1/159-162. 